Vol. 2, No. 04; 2019

ISSN: 2581-4664

\title{
BRAND IMAGE AND CONSUMER PURCHASE INTENTION：AN EMPIRICAL EXPLORATION
}

\author{
Wang Hong \\ School of Economics, Shanghai University, Shanghai, 200444, China \\ http://doi.org/10.35409/IJBMER.2019.2412
}

\begin{abstract}
This paper intends to study the relationship between the cosmetic enterprise corporate social responsibility and the consumer purchase intention by exploring the influence of the brand image of the cosmetic enterprise on the purchase intention of the consumers. It concludes that social responsibility of cosmetic enterprises has a positive influence on the sustainability of the enterprise ; social responsibility of cosmetic enterprises has a positive influence on the brand image of the enterprise; corporate brand image has a positive influence on the consumer purchase intention; the sustainability of the enterprise has a positive effect on the consumer purchase intention; corporate social responsibility has a direct and positive effect on consumer purchase intention; and corporate social responsibility has an indirect and positive effect on consumer purchase intention.
\end{abstract}

Keyword: corporate social responsibility, cosmetic enterprise, consumer purchase intention, corporate brand image, sustainable development

\section{INTRODUCTION}

Currently, the researches on cosmetics enterprises corporate social responsibility (CSR) mostly concern the impact of social responsibility on enterprise performance. The study the sustainable development of cosmetic enterprises from the perspective of consumer psychology needs more effort. Many consumer psychology researchers mainly focus on the consumption characteristics of different age groups, and the purpose of enterprises to take CSR is mainly to increase profits. They often neglect the fact that CSR study from the perspective of consumers can enhance corporate brand

Taking corporate brand image as the entry point, this paper studies the direct influence of corporate social responsibility on consumer purchase intention by establishing a structural equation model. And through the intermediate variable of enterprise sustainability, this paper studies the indirect influence of social responsibility of cosmetic enterprises on consumer purchase intention.

Brand image is an important tool for consumers to predict the quality of products, and is also an important factor affecting customer's quality perception. The brand image of a cosmetic enterprise often produces brand cognition and brand association during the purchase, and consumers' attitude towards the products is determined according to their preferences. 


\section{International Journal of Business Management and Economic Review}

Vol. 2, No. 04; 2019

ISSN: 2581-4664

According to Lieberman and Montgomery (1988), when purchasing products, consumers have brand inertia for the same product due to transfer costs, which results in the repeated purchase of the same brand products. Kamins and Marks (1991) thought that consumers have a higher purchase intention for products of familiar brands and the purchase intention will decrease if the brand is unfamiliar to them. The research of Wall, Liefeld and Heslop (1992) found that consumers have high perceived quality for brands with high reputation. For example, in the cosmetic industry, customers will give priority to products of high-profile brands such as Lancome and Estee Lauder when buying cosmetics. Aaker (1998) believed that a highly recognized brand will create emotional connections between enterprises and consumers, and enable consumers to generate purchase preferences, which results in purchase intention.

The content of brand image is mainly composed of the following two aspects: (1)Tangible Features associated with a brand product or service; (2)Intangible The unique charm of the brand and the personality traits owned by the brand.

In the field of psychology, intention is also called behavioral intention, which refers to the tendency of people to respond to something or a phenomenon. Fishbein (1975) thought that intention is the probability of people to make a specific behavior. He also believes that if one wants to know whether a person will take a given action, the simplest way is to figure out whether he has the will to do it. Granbois and

Summers (1977) held that behavior can be predicted by observing one's behavioral intentions.

In 1985, Monre and Krishnan put forward a price effect model to study product price, perceived quality, perceived value and purchase intention. The main conclusion of this model is that prices will affect consumers' purchase intention through consumers' perceived quality, perceived sacrifice and perceived value. Rao and Monroe (1989) believed that price, brand, enterprise name and brand origin serve as important signals in consumers' product quality perception. Wang Lifang (2005) pointed out that the external clues of products such as price and warranty will affect the consumer's purchase intention through perceived quality, perceived value and perceived risk.

Behavioral intention plays a decisive role in behavior implementation. Therefore, corporate managers can predict consumers' purchase behavior by observing consumers' purchase intention. Mullet (1985) stated that consumers' purchase intention is composed of consumers' attitudes towards certain products as well as some other subjective factors in the decision-making process, so the purchase intention is a powerful tool to predict consumers' purchase behavior.

In short, consumer purchase intention refers to a psychological activity of consumers, and is the possibility of a consumer to buy a commodity. This paper intends to study the relationship between the cosmetic enterprise corporate social responsibility and the consumer purchase intention by exploring the influence of the brand image of the cosmetic enterprise on the purchase intention of the consumers.

\section{REFLECTIONS AND HYPOTHESIS:}

Based on the relevant literature review, some hypothesis are put forward in terms of the following relationships.

The relationship between social responsibility of cosmetic enterprises and the sustainability of enterprises 


\section{International Journal of Business Management and Economic Review}

Vol. 2, No. 04; 2019

ISSN: 2581-4664

Assuming corporate social responsibility can create a sound internal and external environment for enterprises to pursue sustainable development, enhance competitiveness, and achieve sustained profitability. Meanwhile, shouldering

corporate social responsibility is also conducive to the maintenance of sustainable

resource supply and the accomplishment of comprehensive and coordinated social and economic development. Therefore, this paper proposes the following hypothesis:

H1 : Social responsibility of cosmetic enterprises has a positive influence on the sustainability of the enterprise.

The relationship between corporate social responsibility and brand image of cosmetic enterprises

By studying relevant research literature, Marin and Ruiz stated that enterprises' active commitment to social responsibility can help improve the brand image of the enterprises, which is mainly embodied in the following three aspects:

(1) Corporate social responsibility has a spillover effect on the enterprise brand image.

(2) Corporate social responsibility can accelerate the recognition process of the consumer to the enterprise.

(3) The enterprise's active commitment to social responsibility can upgrade the competitive advantage of the enterprise.

Therefore, this paper builds the following hypothesis.

$\mathrm{H} 2$ : Social responsibility of cosmetic enterprises has a positive influence on the brand image of the enterprise.

The relationship between the brand image of enterprises and the consumers' purchase intention

In a competitive market, enterprises have to build up a good brand name to win the attention and trust of consumers. It is believed that the key to winning the fierce competition and finally realizing the corporate goals of subsistence and development lies in good brand images, high popularity, and leadership in the new trends. Greatly improving the competitiveness of enterprises, a good brand image is a main appeal to consumers to purchase the products of the enterprises. Therefore, this paper puts forward the following hypothesis:

H3 : Corporate brand image has a positive influence on consumers' purchase intention.

The relationship between the sustainable development of the enterprise and the consumer's purchase intention

In the purchasing process, customers may face all kinds of risks and every customer attempts to reduce or avoid such risks. In the product-selecting process, the perception of a long corporate culture and a sustainable business strategy will reduce consumers' perception of risks and generate purchase intention. Especially in the cosmetic industry, consumers will be more inclined to buy natural and non-additive cosmetics, so enterprises must realize "green production" and "sustainable management" so as to win customers' trust. paper puts forward the following hypothesis: 


\section{International Journal of Business Management and Economic Review}

Vol. 2, No. 04; 2019

ISSN: 2581-4664

$\mathrm{H} 4:$ The sustainability of the enterprise has a positive effect on the consumer purchase intention.

The relationship between corporate social responsibility of cosmetic enterprise and consumer purchase intention

Through previous study, the corporate social responsibility is positively associated with the brand image of the enterprise, and brand image is positively correlated with consumer purchase intention. Therefore, the corporate social responsibility has an indirect positive influence on consumer's purchase intention. Additionally, some scholars have studied the relationship between corporate social responsibility and consumer purchase intention, and believed that such positive correlation does exist. The commitment of CSR reflects the concern of enterprises to consumers, and such concern will finally promote the overall impression of the society on the enterprises. Robert's (2011) research showed that consumers are willing to pay higher prices for the products and services produced by enterprises with an awareness of social responsibility. Therefore, this paper puts forward the following hypotheses:

H5 : Corporate social responsibility has a direct and positive effect on consumer purchase intention.

H6 : corporate social responsibility has an indirect and positive effect on consumer purchase intention.

Based on the hypotheses above, this paper builds a model (Figure 1) to reflect the influence of cosmetic enterprise SCR on consumer purchase intention.

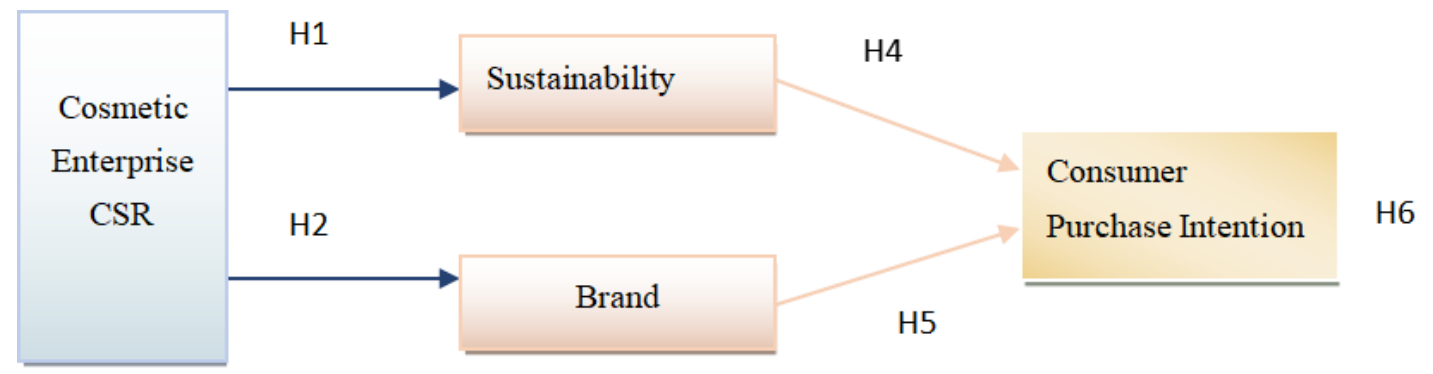

Figure 1 the Influence of Cosmetic CSR on Consumer Purchase Intention

\section{METHODS}

Questionnaire Design

Cosmetic Enterprises CSR Scale

Based on the CSR Pyramid Model (Carroll, 1999) and the characteristics of cosmetic enterprises, this paper divides cosmetic enterprise CSR into four types: economic responsibilities, legal responsibilities, ethical responsibilities and charitable responsibilities. Table 1 is the preliminary questionnaire about cosmetic enterprise CSR.

The questionnaire is designed in the form of Likert scale, and the numbers 1, 2, 3, 4, 5 each represents different degree of approval.

1. Strongly disagree

2. Disagree 


\section{International Journal of Business Management and Economic Review}

Vol. 2, No. 04; 2019

ISSN: 2581-4664

3. Neither agree nor disagree

4. Agree

5. Strongly agree

In the following sections, all the other questionnaires have the same format as the first one (Table 1).

Table 1 Preliminary Questionnaire about Cosmetic Enterprise CSR

\begin{tabular}{|c|c|c|c|}
\hline Variable & \multirow{13}{*}{$\begin{array}{l}\text { Dimensions } \\
\\
\text { Economic } \\
\text { Responsibil } \\
\text { ities }\end{array}$} & Number & Contents \\
\hline \multirow{12}{*}{$\begin{array}{l}\text { Cosmetic } \\
\text { Enterprise } \\
\text { CSR }\end{array}$} & & A1 & Cosmetic Enterprises should pursue maximum profits. \\
\hline & & A2 & Cosmetic Enterprises should have sound operation mode. \\
\hline & & A3 & $\begin{array}{l}\text { Cosmetic Enterprises should improve their economic } \\
\text { benefit. }\end{array}$ \\
\hline & & A4 & $\begin{array}{l}\text { Cosmetic Enterprises should fulfill the contractual } \\
\text { obligation. }\end{array}$ \\
\hline & & A5 & $\begin{array}{l}\text { Cosmetic Enterprises should follow the professional } \\
\text { standards. }\end{array}$ \\
\hline & & A6 & $\begin{array}{l}\text { Cosmetic Enterprises cannot break the law for economic } \\
\text { benefits. }\end{array}$ \\
\hline & & A7 & $\begin{array}{l}\text { Cosmetic Enterprises should offer employees statutory } \\
\text { working conditions. }\end{array}$ \\
\hline & & A8 & Cosmetic Enterprises should ensure the product quality. \\
\hline & & A9 & Cosmetic Enterprises should not make false advertisement. \\
\hline & & A10 & $\begin{array}{l}\text { Cosmetic Enterprises should follow specific moral } \\
\text { principles. }\end{array}$ \\
\hline & & A11 & $\begin{array}{l}\text { Cosmetic Enterprises should take an active part in } \\
\text { charitable events. }\end{array}$ \\
\hline & & A12 & Cosmetic Enterprises should donate to charity. \\
\hline
\end{tabular}




\section{International Journal of Business Management and Economic Review}

Vol. 2, No. 04; 2019

ISSN: $2581-4664$

\begin{tabular}{|l|l|l|l|}
\hline \hline & A13 & Cosmetic Enterprises should join in anti-poverty projects \\
\hline
\end{tabular}

Corporate Sustainability Scale

By reviewing previous theory about corporate sustainability and referring to scales of other relevant organizations, this paper designs preliminary questionnaire to research on corporate sustainability in cosmetic industry (Table 2).

\section{Table 2 Preliminary Questionnaire about Corporate Sustainability}

\begin{tabular}{|c|l|l|}
\hline Variable & Number & Contents \\
\hline \multirow{3}{*}{ Corporate } & B1 & $\begin{array}{l}\text { If a cosmetic enterprise produces pure natural products, you will } \\
\text { recommend the its products to others. }\end{array}$ \\
\cline { 2 - 3 } Sustainability & $\begin{array}{l}\text { If a cosmetic enterprise can maintain sustainable management, you will } \\
\text { pay attention to the development of the enterprise. }\end{array}$ \\
\cline { 2 - 3 } & B3 & $\begin{array}{l}\text { A cosmetic enterprise with a business strategy of 'sustainable } \\
\text { development' is better than a similar company pursuing only profit } \\
\text { maximization. }\end{array}$ \\
\hline
\end{tabular}

\section{Corporate Brand Image Scale}

According to the survey conducted by Manfred(2004)on corporate brand image, the corresponding questionnaire is developed (Table 3 ).

Table 3 Preliminary Questionnaire about Corporate Brand Image

\begin{tabular}{|c|l|l|}
\hline Variable & Number & Contents \\
\hline \multirow{2}{*}{\begin{tabular}{c} 
Corporate \\
Brand \\
\multirow{2}{*}{ Image }
\end{tabular}} & $\mathrm{C} 1$ & You prefer products with a good brand image. \\
\cline { 2 - 3 } & $\mathrm{C} 2$ & You will regret the failure of a cosmetic enterprise with a good brand image. \\
\cline { 2 - 3 } & C3 & A cosmetic enterprise with a good brand image is more competitive in the industry \\
\hline
\end{tabular}

\section{Consumer Purchase Intention Scale}

The following questionnaire (Table 4) is designed on the basis of the consumer purchase intention scale of Zeithaml $(1998 ; 2000)$ and relevant researches done by Grewal et al (1998), Sun and Lin (2010) and Mohd et al (2018). 


\section{International Journal of Business Management and Economic Review}

Vol. 2, No. 04; 2019

ISSN: 2581-4664

\section{Table 4 Preliminary Questionnaire about Consumer Purchase Intention}

\begin{tabular}{|c|l|l|}
\hline Variable & Number & Contents \\
\hline \multirow{3}{*}{$\begin{array}{c}\text { Consumer } \\
\text { Purchase }\end{array}$} & D1 & $\begin{array}{l}\text { If a cosmetic enterprise has a better corporate brand image, you will give } \\
\text { preference to its products. }\end{array}$ \\
\cline { 2 - 3 } \begin{tabular}{c} 
Intention \\
\cline { 2 - 3 }
\end{tabular} & D3 & $\begin{array}{l}\text { If a cosmetic enterprise has a good corporate brand image, you will buy other } \\
\text { related products of this enterprise. }\end{array}$ \\
\cline { 2 - 3 } & D4 & $\begin{array}{l}\text { If a cosmetic enterprise has a good corporate brand image, you are willing to try } \\
\text { new products of this enterprise. }\end{array}$ \\
\hline
\end{tabular}

\section{Sample Distribution}

By analyzing the basic information of the respondents, we have a perceptual knowledge of the sample. The personal information collected though the questionnaire includes the respondent's gender (Table 5), age (Table 6), education (Table 7), monthly income (Table 8), occupation (Table 9) and hometown (Table 10).

\section{Details}

\section{Table 5 Gender}

\begin{tabular}{|l|l|r|r|r|r|}
\hline \multicolumn{2}{|c|}{} & \multicolumn{1}{|c|}{ Frequency } & Percentage & Valid Percentage & $\begin{array}{c}\text { Cumulative } \\
\text { percentage }\end{array}$ \\
\hline \multirow{3}{*}{ Valid } & Male & 40 & 15.7 & 15.7 & 15.7 \\
\cline { 2 - 6 } & Female & 215 & 84.3 & 84.3 & 100.0 \\
\cline { 2 - 6 } & Sum & 255 & 100.0 & 100.0 & \\
\hline
\end{tabular}

Table 6 Age

\begin{tabular}{|r|l|r|r|r|r|}
\hline \multicolumn{2}{|c|}{} & Frequency & Percentage & Valid Percentage & \multicolumn{1}{c|}{$\begin{array}{c}\text { Cumulative } \\
\text { percentage }\end{array}$} \\
\hline \multirow{5}{*}{ Valid } & Below 18 & 7 & 2.7 & 2.7 & 2.7 \\
\cline { 2 - 6 } & $18-30$ & 178 & 69.8 & 69.8 & 72.5 \\
\cline { 2 - 6 } & $31-40$ & 33 & 12.9 & 12.9 & 85.5 \\
\cline { 2 - 6 } & $41-50$ & 24 & 9.4 & 9.4 & 94.9 \\
\cline { 2 - 6 } & Above 50 & 13 & 5.1 & 5.1 & 100.0 \\
\cline { 2 - 6 } & Sum & 255 & 100.0 & 100.0 & \\
\hline
\end{tabular}

Table 7 Education Level 
International Journal of Business Management and Economic Review

Vol. 2, No. 04; 2019

ISSN: 2581-4664

\begin{tabular}{|l|l|r|r|r|r|}
\hline \hline \multicolumn{1}{|c|}{} & \multicolumn{1}{|c|}{ Frequency } & Percentage & \multicolumn{1}{|c|}{$\begin{array}{c}\text { Valid } \\
\text { Percentage }\end{array}$} & $\begin{array}{c}\text { Cumulative } \\
\text { percentage }\end{array}$ \\
\hline \multirow{5}{*}{ Valid } & $\begin{array}{l}\text { Junior high and } \\
\text { below }\end{array}$ & 10 & 3.9 & 3.9 & 3.9 \\
\cline { 2 - 6 } & $\begin{array}{l}\text { Senior } \\
\text { high/Technical } \\
\text { school }\end{array}$ & 23 & 9.0 & 9.0 & 12.9 \\
\cline { 2 - 6 } & Junior college & 28 & 11.0 & 11.0 & 23.9 \\
\cline { 2 - 6 } & Undergraduate & 115 & 45.1 & 45.1 & 69.0 \\
\cline { 2 - 6 } & $\begin{array}{l}\text { Postgraduate and } \\
\text { above }\end{array}$ & 79 & 31.0 & 31.0 & 100.0 \\
\cline { 2 - 6 } & Sum & 255 & 100.0 & 100.0 & \\
\hline
\end{tabular}

Table 8 Monthly Incomes

\begin{tabular}{|l|l|r|r|r|r|}
\hline \multicolumn{2}{|c|}{} & \multicolumn{1}{|c|}{ Frequency } & Percentage & \multicolumn{1}{c|}{$\begin{array}{c}\text { Valid } \\
\text { Percentage }\end{array}$} & \multicolumn{2}{c|}{$\begin{array}{c}\text { Cumulative } \\
\text { percentage }\end{array}$} \\
\hline \multirow{5}{*}{ Valid } & Below 2000 & 60 & 23.5 & 23.5 & 23.5 \\
\cline { 2 - 6 } & $2000-4000$ & 78 & 30.6 & 30.6 & 54.1 \\
\cline { 2 - 6 } & $4000-6000$ & 52 & 20.4 & 20.4 & 74.5 \\
\cline { 2 - 6 } & $6000-8000$ & 34 & 13.3 & 13.3 & 87.8 \\
\cline { 2 - 6 } & Above 8000 & 31 & 12.2 & 12.2 & 100.0 \\
\cline { 2 - 6 } & Sum & 255 & 100.0 & 100.0 & \\
\hline
\end{tabular}

Table 9 Occupation

\begin{tabular}{|l|l|r|r|r|r|}
\hline \multicolumn{2}{|c|}{} & \multicolumn{1}{|c|}{ Frequency } & Percentage & \multicolumn{1}{c|}{$\begin{array}{c}\text { Valid } \\
\text { Percentage }\end{array}$} & \multicolumn{2}{c|}{$\begin{array}{c}\text { Cumulative } \\
\text { percentage }\end{array}$} \\
\hline \multirow{7}{*}{ Valid } & Student & 75 & 29.4 & 29.4 & 29.4 \\
\cline { 2 - 6 } & Civil Servant & 22 & 8.6 & 8.6 & 38.0 \\
\cline { 2 - 6 } & Employee & 72 & 28.2 & 28.2 & 66.3 \\
\cline { 2 - 6 } & Self-employed & 46 & 18.0 & 18.0 & 84.3 \\
\cline { 2 - 6 } & Other & 40 & 15.7 & 15.7 & 100.0 \\
\cline { 2 - 6 } & Sum & 255 & 100.0 & 100.0 & \\
\hline
\end{tabular}

Table 10 Hometown 


\section{International Journal of Business Management and Economic Review}

Vol. 2, No. 04; 2019

ISSN: 2581-4664

\begin{tabular}{|c|l|r|c|c|c|}
\hline \hline \multicolumn{2}{|c|}{} & Frequency & Percentage & $\begin{array}{c}\text { Valid } \\
\text { Percentage }\end{array}$ & Cumulative percentage \\
\hline \multirow{4}{*}{} & Eastern China & 189 & 74.1 & 74.1 & 74.1 \\
\cline { 2 - 6 } & Northern China & 14 & 5.5 & 5.5 & 79.6 \\
\cline { 2 - 6 } & Central China & 19 & 7.5 & 7.5 & 87.1 \\
\cline { 2 - 6 } & Southern China & 5 & 2.0 & 2.0 & 89.0 \\
\cline { 2 - 6 } & Northeast China & 9 & 3.5 & 3.5 & 92.5 \\
\cline { 2 - 6 } & Northwest China & 14 & 5.5 & 5.5 & 98.0 \\
\cline { 2 - 6 } & Southwest China & 5 & 2.0 & 2.0 & 100.0 \\
\cline { 2 - 6 } & Sum & 255 & 100.0 & 100.0 & \\
\hline
\end{tabular}

From the statistical results above, the distribution of the respondents has the following characteristics:

(1) From Table 5, the number of women is more than that of men, because women are the main consumers of cosmetics, but in this paper, we do not ignore the existence of male consumers.

(2) From Table 6, the respondents were mainly concentrated in the 18-30 age group, because people in this age group are most concerned with nursing and skin maintenance.

(3) From Table 7, most of the respondents were with an education level of undergraduate and above. People in this group usually have a higher level literacy, so they can better understand and fill out the questionnaire.

(4) From Table 8, the respondents were mainly students, employees and self-employed persons. A large proportion of them were loyal customers of cosmetics.

(4) From Table 8, the respondents were mainly students, employees and self- employed persons. A large proportion of them were loyal customers of cosmetics.

To sum up, most of the respondents involved in the research met the requirements of this paper. Intuitively, the credibility of the respondents is relatively high.

\section{Descriptive statistics}

Through descriptive statistics, we have an overall understanding of the data as a whole. This paper selects 8 main statistics, including sample number, minimum value, maximum value, mean, standard deviation, variance, skewness and kurtosis, to summarize the statistical result (as Table 11 shows).

\section{Table 11 Descriptive Statistics}

\begin{tabular}{|l|c|r|r|r|r|r|r|r|r|r|r|}
\hline Variables & $\mathrm{N}$ & Min & Max & \multicolumn{2}{|c|}{ Mean } & \multicolumn{1}{c|}{$\begin{array}{c}\text { Standard } \\
\text { deviation }\end{array}$} & $\begin{array}{c}\text { Varianc } \\
\mathrm{e}\end{array}$ & \multicolumn{2}{|c|}{ Skewness } & \multicolumn{2}{c|}{ Kurtosis } \\
& Valve & Value & Value & Value & \multicolumn{1}{c|}{ SE } & Value & Value & Value & SE & Value & SE \\
\hline A1 & 255 & 1 & 5 & 4.58 & .052 & .833 & .694 & -2.366 & .153 & 5.739 & .304 \\
\hline
\end{tabular}




\section{International Journal of Business Management and Economic Review}

Vol. 2, No. 04; 2019

ISSN: 2581-4664

\begin{tabular}{|c|c|c|c|c|c|c|c|c|c|c|c|}
\hline $\mathrm{A} 2$ & 255 & 1 & 5 & 4.62 & .050 & .798 & .637 & -2.633 & .153 & 7.357 & .304 \\
\hline A3 & 255 & 1 & 5 & 4.67 & .050 & .799 & .639 & -2.877 & .153 & 8.346 & .304 \\
\hline A4 & 255 & 1 & 5 & 4.66 & .047 & .746 & .556 & -2.966 & .153 & 6.006 & .304 \\
\hline A5 & 255 & 1 & 5 & 4.68 & .047 & .751 & .564 & -3.169 & .153 & 5.229 & .304 \\
\hline A6 & 255 & 1 & 5 & 4.71 & .046 & .737 & .544 & -3.350 & .153 & 5.371 & .304 \\
\hline A7 & 255 & 1 & 5 & 4.68 & .043 & .679 & .462 & -2.771 & .153 & 9.125 & .304 \\
\hline A8 & 255 & 1 & 5 & 4.74 & .042 & .674 & .454 & -3.206 & .153 & 5.807 & .304 \\
\hline A9 & 255 & 1 & 5 & 4.74 & .044 & .696 & .484 & -3.420 & .153 & 5.163 & .304 \\
\hline A10 & 255 & 1 & 5 & 4.66 & .046 & .730 & .533 & -2.739 & .153 & 8.906 & .304 \\
\hline A11 & 255 & 1 & 5 & 4.53 & .064 & 1.023 & 1.046 & -2.374 & .153 & 4.874 & .304 \\
\hline A12 & 255 & 1 & 5 & 4.65 & .053 & .847 & .717 & -2.898 & .153 & 8.517 & .304 \\
\hline A13 & 255 & 1 & 5 & 4.60 & .053 & .840 & .706 & -2.613 & .153 & 7.398 & .304 \\
\hline B1 & 255 & 1 & 5 & 4.29 & .060 & .952 & .906 & -1.347 & .153 & 1.460 & .304 \\
\hline $\mathrm{B} 2$ & 255 & 1 & 5 & 4.23 & .064 & 1.018 & 1.037 & -1.312 & .153 & 1.099 & .304 \\
\hline B3 & 255 & 1 & 5 & 4.25 & .062 & .989 & .978 & -1.293 & .153 & 1.096 & .304 \\
\hline $\mathrm{C} 1$ & 255 & 1 & 5 & 4.25 & .062 & .989 & .978 & -1.318 & .153 & 1.273 & .304 \\
\hline $\mathrm{C} 2$ & 255 & 1 & 5 & 4.09 & .067 & 1.072 & 1.150 & -1.022 & .153 & .349 & .304 \\
\hline $\mathrm{C} 3$ & 255 & 1 & 5 & 4.16 & .066 & 1.053 & 1.109 & -1.215 & .153 & .866 & .304 \\
\hline D1 & 255 & 1 & 5 & 3.93 & .082 & 1.304 & 1.699 & -.925 & .153 & -.438 & .304 \\
\hline D2 & 255 & 1 & 5 & 3.85 & .081 & 1.293 & 1.671 & -.778 & .153 & -.677 & .304 \\
\hline D3 & 255 & 1 & 5 & 3.88 & .081 & 1.288 & 1.658 & -.808 & .153 & -.649 & .304 \\
\hline D4 & 255 & 1 & 5 & 3.92 & .082 & 1.305 & 1.702 & -.883 & .153 & -.567 & .304 \\
\hline Valid N & 255 & & & & & & & & & & \\
\hline
\end{tabular}

Huang Fangming (2005) pointed out that if the absolute value of skewness is less than 3 and of kurtosis less than 10, the variable can be considered to obey normal distribution. From the table above, it is obvious that all the variables accord with the condition mentioned by Huang, so it can be assumed that the samples obey normal distribution.

\section{RESULT ANALYSIS}

Reliability and Validity Analysis

Reliability Analysis

In order to ensure the stability and reliability of the questionnaire, this paper applies the Cronbach's Alpha coefficient to examine the internal consistency of the scales. Generally, it is believed that a scale is relatively reliable with a Cronbach's Alpha coefficient greater than 0.7.

(1) Reliability Analysis on Cosmetic Enterprise CSR Scale (in Table 12)

\section{Table 12 Reliability Analysis on Cosmetic Enterprise CSR Scale}

$$
\text { Cronbach's Alpha }
$$

$\mathrm{N}$ 


\section{International Journal of Business Management and Economic Review}

Vol. 2, No. 04; 2019

ISSN: 2581-4664

\section{.950}

13

(2) Reliability Analysis on Corporate Brand Image Scale (in Table13)

Table 13 Reliability Analysis on Corporate Brand Image Scale

\begin{tabular}{|c|c|}
\hline Cronbach's Alpha & N \\
\hline .864 & 3 \\
\hline
\end{tabular}

(3) Reliability Analysis on Corporate Sustainability Scale (in Table14)

Table 14 Reliability Analysis on Corporate Sustainability Scale

\begin{tabular}{|c|c|}
\hline Cronbach's Alpha & $\mathrm{N}$ \\
\hline .945 & 3 \\
\hline
\end{tabular}

(4) Reliability Analysis on Consumer Purchase Intention Scale (in Table 15)

Table 15 Reliability Analysis on Consumer Purchase Intention Scale

\begin{tabular}{|c|c|}
\hline Cronbach's Alpha & N \\
\hline .946 & 4 \\
\hline
\end{tabular}

(5) Result of Reliability Analysis

From the computed results, the Cronbach's Alpha coefficients of all the four scales are well above 0.7 . As a result, the questionnaire as a whole enjoys a relatively high reliability and there is no need to remove any of the questionnaire item.

\section{Validity Analysis}

(1) Bartlett's test and Kaiser-Meyer-Olkin test

In this paper, the Bartlett test and KMO test are carried out by SPSS19.0. The purpose of the test is to examine the variable correlation and study whether there is a need for factor analysis.

Table 16 KMO test and Bartlett test

\begin{tabular}{|l|l|r|}
\hline \multicolumn{2}{|l|}{ Kaiser-Meyer-Olkin Measure of Sampling Adequacy } & .905 \\
\hline \multirow{4}{*}{ Bartlett's Test of Sphericity } & Approx. Chi-Square & 5615.389 \\
\cline { 2 - 3 } & Df & 253 \\
\cline { 2 - 3 } & Sig. & .000 \\
\hline
\end{tabular}




\section{International Journal of Business Management and Economic Review}

Vol. 2, No. 04; 2019

ISSN: 2581-4664

The Analysis result (Table16) shows that the KMO value is 0.905 (closer to 1), indicating that the 23 variables shown in the questionnaire are well correlated. Meanwhile, the test value of Bartlett's Test is $5615.389, \mathrm{P}=0.000<0.001$, meaning that the correlation matrix of the 23 variables is not a unit matrix and that the information reflected by these variables has a certain overlap. In conclusion, the structural validity among the variables of this questionnaire is quite good and therefore factor analysis is practicable.

(2) Factor Analysis

Factor Analysis is a statistical technique to simplify a group of variables. By using this technique, highly correlated variables are grouped into the same factor, and as a result, the number of variable is reduced and the original information can be described by only a few factors. In this paper, the principal component analysis is used to extract the factor whose eigenvalue is greater than 1. As is demonstrated in Table 5- 6, four factors are extracted from 23 variables in the questionnaire. The extracted factors explain most of the variance of the original variable (75.026\%), showing that they well reflect the information carried by the original variables (in Table 17).

\section{Table 17 Total Variance Explained}

\begin{tabular}{|c|c|c|c|c|c|c|c|c|c|}
\hline \multirow[t]{2}{*}{$\begin{array}{l}\text { Compone } \\
\text { nt }\end{array}$} & \multicolumn{3}{|c|}{ Initial eigenvalues } & \multicolumn{3}{|c|}{$\begin{array}{c}\text { Extraction Sums of Squared } \\
\text { Loadings } \\
\end{array}$} & \multicolumn{3}{|c|}{$\begin{array}{c}\text { Rotation Sums of Squared } \\
\text { Loadings } \\
\end{array}$} \\
\hline & Total & $\begin{array}{c}\% \text { of } \\
\text { Variance }\end{array}$ & $\begin{array}{c}\text { Cumulati } \\
\text { ve } \%\end{array}$ & Total & $\begin{array}{c}\% \text { of } \\
\text { Variance }\end{array}$ & $\begin{array}{c}\text { Cumulati } \\
\text { ve } \%\end{array}$ & Total & $\begin{array}{c}\% \text { of } \\
\text { Variance }\end{array}$ & $\begin{array}{c}\text { Cumulati } \\
\text { ve } \%\end{array}$ \\
\hline 1 & 10.326 & 44.895 & 44.895 & 10.326 & 44.895 & 44.895 & 8.205 & 35.675 & 35.675 \\
\hline 2 & 3.265 & 14.195 & 59.090 & 3.265 & 14.195 & 59.090 & 3.662 & 15.920 & 51.596 \\
\hline 3 & 2.210 & 9.610 & 68.700 & 2.210 & 9.610 & 68.700 & 2.793 & 12.143 & 63.739 \\
\hline 4 & 1.455 & 6.326 & 75.026 & 1.455 & 6.326 & 75.026 & 2.596 & 11.287 & 75.026 \\
\hline 5 & .936 & 4.071 & 79.097 & & & & & & \\
\hline 6 & .715 & 3.109 & 82.205 & & & & & & \\
\hline 7 & .623 & 2.708 & 84.914 & & & & & & \\
\hline 8 & .451 & 1.961 & 86.875 & & & & & & \\
\hline 9 & .424 & 1.843 & 88.718 & & & & & & \\
\hline 10 & .394 & 1.712 & 90.430 & & & & & & \\
\hline 11 & .294 & 1.280 & 91.710 & & & & & & \\
\hline 12 & .247 & 1.073 & 92.783 & & & & & & \\
\hline 13 & .224 & .972 & 93.755 & & & & & & \\
\hline 14 & .201 & .873 & 94.628 & & & & & & \\
\hline 15 & .195 & .849 & 95.478 & & & & & & \\
\hline 16 & .180 & .782 & 96.260 & & & & & & \\
\hline
\end{tabular}




\section{International Journal of Business Management and Economic Review}

Vol. 2, No. 04; 2019

ISSN: 2581-4664

\begin{tabular}{|l|r|r|r|l|l|l|l|l|l|}
\hline \hline 17 & .175 & .762 & 97.022 & & & & & & \\
\hline 18 & .153 & .665 & 97.687 & & & & & & \\
\hline 19 & .139 & .603 & 98.290 & & & & & & \\
\hline 20 & .126 & .548 & 98.838 & & & & & & \\
\hline 21 & .111 & .484 & 99.321 & & & & & & \\
\hline 22 & .097 & .422 & 99.744 & & & & & & \\
\hline 23 & .059 & .256 & 100.000 & & & & & & \\
\hline
\end{tabular}

Extraction Method : Principal Component Analysis

In order to further clarify the structure of the extracted factors, Varimax rotation is applied to obtain the rotated component matrix. From Table 18, the first factor is mainly related to the components of A1, A2, A3, A4, A5, A6, A7, A8, A9, A10, A11, A12 and A13. Factor 1 is named Cosmetic Enterprise CSR. The second factor consists of D1, D2, D3 and D4, representing Consumer Purchase Intention. B1, B2 and B3 reduce to Factor 3, the Corporate Sustainability. The forth factor, meaning Corporate Reputation, represents the remaining three variables, $\mathrm{C} 1$, $\mathrm{C} 2$, and $\mathrm{C} 3$.

Table 18 Rotated Component Matrix

\begin{tabular}{|l|r|r|r|l|}
\hline \multicolumn{7}{|c|}{ Rotated Component Matrix } \\
\hline & Factor 1 & Factor 2 & Factor 3 & Factor 4 \\
\hline & .748 & & & \\
\hline A1 & .817 & & & \\
\hline A2 & .801 & & & \\
\hline A3 & .854 & & & \\
\hline A4 & .870 & & & \\
\hline A5 & .867 & & & \\
\hline A6 & .794 & & & \\
\hline A7 & .792 & & & \\
\hline A8 & .843 & & & \\
\hline A9 & .729 & & & \\
\hline A10 & .519 & & & \\
\hline A11 & .687 & & & \\
\hline A12 & .661 & & & \\
\hline A13 & & & & \\
\hline B1 & & & & \\
\hline
\end{tabular}




\section{International Journal of Business Management and Economic Review}

Vol. 2, No. 04; 2019

ISSN: 2581-4664

\begin{tabular}{|l|l|r|r|r|}
\hline \hline B2 & & .907 & .906 \\
\hline B3 & & & .735 \\
\hline C1 & & & .878 \\
\hline C2 & & .888 & & .810 \\
\hline C3 & .902 & & \\
\hline D1 & .930 & & \\
\hline D2 & .915 & & \\
\hline D3 & & & \\
\hline D4 & & & \\
\hline Extraction Method :Principal Component \\
Rotation Method :Varimax
\end{tabular}

Extraction Method :Principal Component Rotation Method :Varimax

To sum up, the overall survey concept of the questionnaire is reasonable, and the whole questionnaire has a high validity.

\section{Construction of Structural Equation Model}

According to the six hypothesizes put forward in the previous sector, this paper set up a structural equation model (SEM) to verify the fitting condition of the hypothesis model and the actual measured data. Through Amos20.0, the initial SEM is displayed in the following figure (Figure 2).

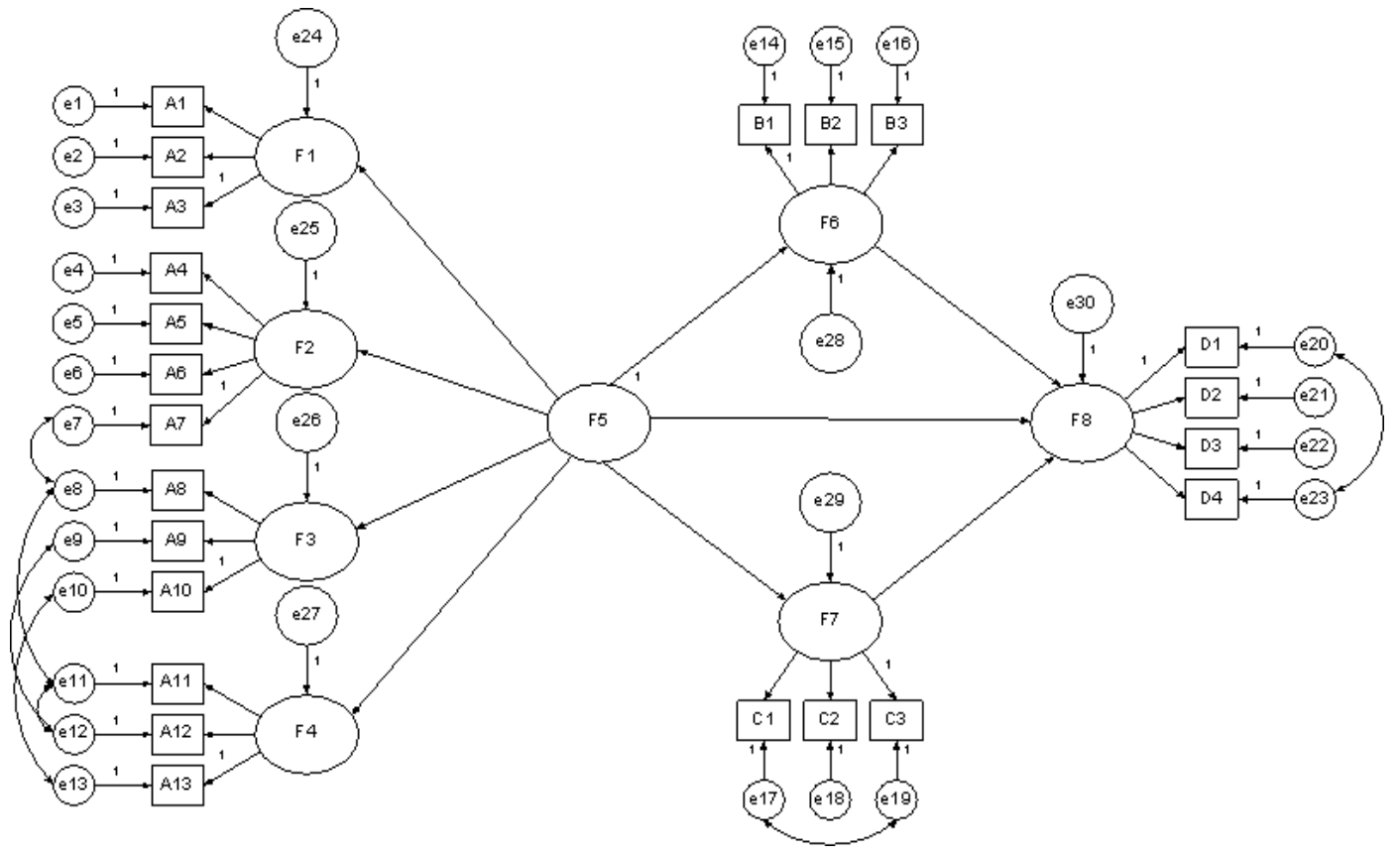




\section{Figure 2 Initial SEM}

F1 is the dimension of economic responsibilities, in which A1, A2, and A3 are potential variables for this dimension. Similarly, F2, F3, F4 stand for legal responsibilities, ethical responsibilities and charitable responsibilities respectively, and they jointly make up F5, which represent cosmetic enterprise CSR dimension. F6 is the Corporate Sustainability dimension, F7 Corporate Brand Image dimension, and F8 Consumer Purchase Intention dimension.

As is shown in Figure 5-1, the path coefficients (standardized) and load coefficients (standardized) are calculated by Amos20.0. In order to inspect the statistical significance of the estimated parameters in the model results, a statistical significance test is needed for the path coefficients and the load coefficients. The test result is illustrated in the following table (Table 19).

Maximum Likelihood Estimation is applied to produce the test result. In the table, Critical Ratio (CR, the ratio of estimated path/load coefficient to the standard deviation) and $\mathrm{P}$ value are used to measure the significance level. Generally, if the absolute value of C.R. (critical ratio) is greater than 1.96 , it is considered that the

Table 19 Regression Weights: (Group number 1 - Default model)

\begin{tabular}{|c|c|c|c|c|c|c|c|}
\hline & & & $\begin{array}{l}\text { Path/Load } \\
\text { Coefficient } \\
\text { Estimated }\end{array}$ & S.E. & Critical Ratio & $\mathrm{P}$ & $\begin{array}{c}\text { Path/Load } \\
\text { Coefficient } \\
\text { (standardized) }\end{array}$ \\
\hline F6 & $<---$ & F5 & .337 & .057 & 5.951 & .000 & .380 \\
\hline F7 & $<---$ & F5 & .525 & .059 & 8.966 & .000 & .539 \\
\hline F8 & $<--$ & F5 & .160 & .088 & 1.818 & .069 & .145 \\
\hline F1 & $<--$ & F5 & .500 & .042 & 11.823 & .000 & .866 \\
\hline $\mathrm{F} 2$ & $<---$ & F5 & .556 & .036 & 15.607 & .000 & .910 \\
\hline F3 & $<---$ & F5 & .550 & .039 & 14.090 & .000 & .976 \\
\hline $\mathrm{F} 4$ & $<--$ & F5 & .561 & .047 & 11.898 & .000 & .843 \\
\hline F8 & $<--$ & F6 & .235 & .087 & 2.715 & .007 & .188 \\
\hline F8 & $<--$ & F7 & .243 & .081 & 2.987 & .003 & .078 \\
\hline A3 & $<--$ & $\mathrm{F} 1$ & 1.000 & & & & .724 \\
\hline A2 & $<--$ & $\mathrm{F} 1$ & 1.350 & .085 & 15.880 & .000 & .980 \\
\hline A1 & $<--$ & $\mathrm{F} 1$ & 1.344 & .088 & 15.282 & .000 & .935 \\
\hline A7 & $<--$ & $\mathrm{F} 2$ & 1.000 & & & & .811 \\
\hline A6 & $<--$ & $\mathrm{F} 2$ & 1.158 & .069 & 16.778 & .000 & .867 \\
\hline A5 & $<--$ & $\mathrm{F} 2$ & 1.232 & .069 & 17.964 & .000 & .905 \\
\hline A4 & $<--$ & $\mathrm{F} 2$ & 1.189 & .069 & 17.159 & .000 & .879 \\
\hline
\end{tabular}




\section{International Journal of Business Management and Economic Review}

Vol. 2, No. 04; 2019

ISSN: 2581-4664

\begin{tabular}{|l|l|l|r|r|r|r|r|}
\hline \hline A10 & $<--$ & F3 & 1.000 & & & & .775 \\
\hline A9 & $<--$ & F3 & 1.054 & .070 & 15.100 & .000 & .857 \\
\hline A8 & $<---$ & F3 & .939 & .068 & 13.712 & .000 & .793 \\
\hline D1 & $<--$ & F8 & 1.000 & & & & .851 \\
\hline D2 & $<---$ & F8 & 1.034 & .055 & 18.783 & .000 & .888 \\
\hline D3 & $<--$ & F8 & 1.094 & .053 & 20.582 & .000 & .943 \\
\hline D4 & $<---$ & F8 & 1.064 & .047 & 22.567 & .000 & .905 \\
\hline A13 & $<--$ & F4 & 1.000 & & & & .641 \\
\hline A12 & $<---$ & F4 & .976 & .104 & 9.377 & .000 & .623 \\
\hline A11 & $<--$ & F4 & .856 & .121 & 7.082 & .000 & .453 \\
\hline B1 & $<---$ & F6 & 1.000 & & & & .931 \\
\hline B2 & $<---$ & F6 & 1.045 & .042 & 24.746 & .000 & .910 \\
\hline B3 & $<---$ & F6 & 1.039 & .040 & 26.269 & .000 & .931 \\
\hline C3 & $<--$ & F7 & 1.000 & & & & .927 \\
\hline C2 & $<---$ & F7 & .914 & .074 & 12.274 & .000 & .832 \\
\hline C1 & $<---$ & F7 & .881 & .069 & 12.686 & .000 & .870 \\
\hline
\end{tabular}

Estimation of the parameter reaches a significant level of 0.05, and if the absolute value of C.R. is greater than 2.58, the estimation of the parameter reaches a significant level of 0.01 . Additionally, a $\mathrm{P}$ value less than 0.1 would ensure the significance of corresponding result.

According to the table, all of the estimated path coefficients are positive, and they all reach a relatively high significant level, which indicates that the CSR of the cosmetic enterprises has a direct and indirect influence on the consumer purchase intention. In conclusion, the fitting condition of the SEM is quite good. The observed variables can well explain the characteristics of latent variables, which can verify that the impact of cosmetic CSR on consumer purchase intention is significant.

The research above proves that the fitting condition of the SEM is good, so this paper will estimate the model in the second stage, which is mainly for testing the paper hypotheses. The direct effect, the indirect effect and the total effect of the latent variables of the SEM are shown as follows (Table 20).

Table 20 Relations among Latent Variables

\begin{tabular}{|c|c|c|c|c|}
\hline Independent Variables & Dependent Variables & Direct Effect & Indirect Effect & Total Effect \\
\hline \multirow{2}{*}{$\begin{array}{c}\text { Cosmetic } \\
\text { Enterprises CSR } \\
\text { (F5) }\end{array}$} & $\begin{array}{c}\text { Corporate Sustainability } \\
(\mathrm{F} 6)\end{array}$ & $\begin{array}{l}0.380 * * * \\
(5.951)\end{array}$ & 0.380 \\
\cline { 2 - 5 } & $\begin{array}{c}0.539 * * * \\
(8.966)\end{array}$ & & 0.539 \\
\cline { 2 - 5 } & Corporate Brand Image & $0.145^{* * *}$ & $0.125 * * *$ & 0.270
\end{tabular}




\section{International Journal of Business Management and Economic Review}

Vol. 2, No. 04; 2019

ISSN: 2581-4664

\begin{tabular}{|c|c|c|c|c|}
\hline \hline & Intention (F8) & $(1.818)$ & & 0.188 \\
\cline { 2 - 5 } Corporate Sustainability & Consumer Purchase & $0.188 * * *$ & & $(2.715)$ \\
(F6) & Intention (F8) & 0.078 & & 0.078 \\
\hline Corporate Brand Image & Consumer Purchase & $(1.092)$ & & \\
\hline
\end{tabular}

In Table 5-9, direct effect refers to the direct influence of the causal variable (independent variable) to the outcome variable (dependent variable). Direct effect is measured by path coefficient of the independent variable to the dependent variable, which is shown in the Table 58.

Indirect effect refers to the indirect influence of a causal variable on a result variable by affecting one or more intermediary variables. When there is only one intermediate variable, the indirect effect is reflected by the product of the two path Coefficients.

The total effect is the total influence of the cause variable on the result variable.

It is the sum of the direct and indirect effects.

\section{DISCUSSION}

Based on previous researches and theories in the related field, this paper builds six hypotheses and establishes a structure equation model. The questionnaire respondents are mainly undergraduate and postgraduate students. Three hundred questionnaires are issued to various respondents, and 255 valid questionnaires are collected. EXCEL2007, SPSS19.0 and AMOS20.0 were used to collate and analyze the data obtained from the questionnaire. By constructing the structural equation model to assume and analyze the relationship between latent variables, the following conclusions are drawn.

Social responsibility of cosmetic enterprises has a direct and positive influence on the sustainability of the enterprise (H1).

The direct effect of cosmetic enterprises CSR on the sustainable development of enterprises is 0.380 , and it has reached significant at 0.001 . It can be seen that if a cosmetic enterprise actively undertakes corporate social responsibility, this enterprise can enhance competitiveness of CSR and drive enterprise to achieve sustained profitability, and finally achieve sustainable operation. $\mathrm{So}, \mathrm{H} 1$ is supported.

Social responsibility of cosmetic enterprises has a direct and positive influence on the brand image of the enterprise $(\mathrm{H} 2)$.

The direct effect of cosmetic enterprises CSR on the brand image of enterprises is 0.539 , and it has achieved significant at the 0.001 level. From the result, it can be concluded that the corporate social responsibility can promote the recognition of the consumer to the enterprise. The recognition here refers to consumers' perception of enterprises, which enables consumers to combine their personal values with the corporate values through social responsibility, so the enterprise can establish a good brand image by undertaking social responsibilities. Therefore, H2 is supported.

Corporate brand image has a direct and positive influence on consumers' purchase intention (H3). 


\section{International Journal of Business Management and Economic Review}

Vol. 2, No. 04; 2019

ISSN: 2581-4664

The direct effect of enterprise brand image on consumers' purchase intention is 0.078 , and it has reached significant at the 0.003 level, so it is significant. Therefore, a good corporate image can greatly improve the competitiveness of the enterprise and attract customers to buy its products. Therefore, H3 is supported.

The sustainability of the enterprise has a direct and positive effect on the consumer purchase intention (H4).

The direct effect of the sustainable development of enterprises on consumer purchase intention is 0.188 , and it has achieved the significant level at 0.001 . The result shows that if an enterprise can realize its "sustainable development" goals, both from managerial perspective and from environmental perspective, consumers will be more inclined to purchase the products of this enterprise.

Corporate social responsibility has a direct and indirect positive effect on consumer purchase intention (H5 \& H6).

The direct effect of social responsibility of cosmetic enterprises on consumer purchase intention is 0.145 , and it reaches a significant level at 0.001 , and the indirect effect is 0.125 , which is significant at 0.001 level. So it is true that by actively assuming corporate social responsibilities, enterprises can improve their image and status in consumers' minds, and thus stimulating the purchase desire of consumers. Whether committing social responsibilities or not is an important factor affecting consumers' choice, because consumers believe that an enterprise with a strong awareness of corporate social responsibility is more likely to provide high-quality products and services. Therefore, $\mathrm{H} 5$ and $\mathrm{H} 6$ are supported.

Therefore, all the six hypotheses proposed in this paper are supported by the empirical results. To conclude, a good corporate brand image is not only a warrant of the high product quality but also a symbol of the enterprise's excellent corporate culture and spirit. Cosmetic enterprises should actively fulfill social responsibility. While improving their legal consciousness and human rights awareness, consumers should

also participate in the market supervision process. Through mass media, cosmetic enterprises are put under huge pressure, so they have no other choice but to fulfill social responsibility, produce high quality products, and protect the environment. In this way, consumers can protect their own rights and interests, and promote the CSR awareness cosmetic enterprises as well.

6. Acknowledgement: The author is very grateful for the support of Shen $\mathrm{Li}$ (academic number 14723347), and the assistance from Lei Jie (academic number 17724317), together with Chen Renchao (academic number 14123248). They were postgraduates and undergraduate of School of Economics, Shanghai University.

\section{REFERENCES}

Aaker D.A., Managing Brand Equity, NewYork : Free Press,1991.

Carroll A.B., Corporate social responsibility, Business and Society, 1999,38(3):268-295.

Fishbein M., Ajzen I., Belief, Attitude, Intention, and Behavior: An Introduction to Theory and Research, Reading, Mass, Addison-Wesley,1975.

Granbois D., Summers J.O., and Frazier, G.L., Correlates of Consumer Expectation and 


\section{International Journal of Business Management and Economic Review}

Vol. 2, No. 04; 2019

ISSN: 2581-4664

Complaining Behavior, Consumer Satisfaction, Dissatisfaction and Complaining Behavior, Indiana University Press, 1977.

Grewal D., Monroe KB, Krishman R., The Effects of Price-Comparison Advertising on Buyers' Perceptions of Acquisition Value, Trans-action Value, and Behavioral Intensions, Journals of Marketing, 1998, 62:46-59.

Huang Fangming, Structural Equation Model Theory and Application, Beijing: China Taxation Press, 2005.

Kamins M.A. and L.J Marks., The Perception of Kosher as a Third Party Certification Claim in Advertising for Familiar and Unfamiliar Brands, Journal of the Academy of Marketing Science, 1991(19):177-185.

Liberman M.B. and Montgomery D.B., First-mover (dis)advantages: Retrospective and Link with the Resource-Based View, Strategy Manage,1988(9)41-58.

Manfred Schwaiger, Components and Parameters of Corporate Reputation-An Empirical Study, Schmalenbach Business Review, 2004(56)1: 46-71

Mohd Afag Khan, Sablu Khan, Service Convenience and Post-Purchase Behavior of Online Buyers: An Empirical Study, Journal of Service Science Research, 2018,10(2), 167-188.

Mullet G.M., Analysis of purchase intent scales weighted by probability of actual purchase, Journal of Marketing,1985(22):93-96.

Rao A.R. and K.B. Monroe,The Moderating Effect of Prior Knowledge on Cue Utilization in Product Evaluations, Journal of Consumer Research,1989(15).

Robert B. Gielissen, Why do Customers Buy Socially Responsible Products? International Journal of Business and Social Science, 2011(1)3.

Sun PC and Lin CM, Building Customer Trust and Loyalty: An Empirical Study in a Retailing Context, The Service Industries Journal, 2010, 30(9): 1439-1455.

Wall M.J. Liefeld and L.A.Heslop, Impact of Country of Original Cues on Consumer Judgment in Multi-Cue Situation: A Covariance Analysis, Journal of the Academy of Marketing Science, 1992(2):105-113.

Wang Lifang, The Influence of External Cues on the Purchase Intention of Consumers by Information Asymmetry, Consumer economy, 2005.

Zeithmal VA, Consumer Perceptions of Price, Quality, and Value: A Means-end Model and Synthesis of Evidence, Journal of Marketing, 1988, 52:2-22.

Zeithmal VA, Bitner MJ, Services Marketing: Integrating Customer Focus Across the Firm, Boston: McGraw-Hill, 2000. 